3. Скибицкий Э.Г., Скибицкая И.Ю. Роль фасилитатора при подготовке магистрантов в образовательной организации. М. : ИСГУ, 2018. C. $95-104$.

4. Шаполова В.В. Ефективність методу графічної фасилітації під час вдосконалення комунікативних умінь майбутніх менеджерів. Наук.практ. журнал «Теорія та практика управління соціальними системами/ заг. ред. О.Г. Романовський. Х: НТУ «ХПІ», 2020. № 2. С. 66-79.

5. Sibbet, D. Visual intelligence: Using the deep patterns of visual language to build cognitive skills. Theory into Practice, 47, 118-127. [Електронний pecypc]. - Режим доступу: https://doi.org/10.1080/ 00405840801992306.

DOI https://doi.org/10.30525/978-9934-588-80-8-1.25

\title{
ЕКСПРЕС-МЕТОДИКИ ЯК ІНСТРУМЕНТ ОПТИМІЗАЦІї ПСИХОДІАГНОСТИЧНОЇ РОБОТИ ПРАКТИЧНОГО ПСИХОЛОГА
}

\author{
Красильников I. O. \\ кандидат психологічних наук, дочент, \\ практичний психолог \\ Комунальний заклад «Полтавська гімназія № 6 \\ Полтавської міської ради Полтавської області» \\ Муліка К. М. \\ методист навчально-методичного кабінету психологічної служби \\ Полтавського обласного інституту післядипломної \\ педагогічної освіти імені М. В. Остроградського, \\ аспірант лабораторії психології політико-правових відносин \\ Інститут сочіальної та політичної психології АПН \\ м. Полтава, Украӥна
}

Ефективність роботи психолога у закладі освіти визначається не лише його особистісно-професійною компетентністю, але і тими об'єктивними, соціальними умовами, у яких здійснюється психологічна діяльність: правовими, організаційними, соціально-економічними тощо. Особливості практичної діяльності психолога у закладі освіти, на відміну від інших соціальних сфер, полягають у значному об'ємі цільових груп - учні, педагоги, батьки, охопити які психодіагностичними, психокорекційними, психологічно консультативними та іншими 98 
формами роботи досить складно. У професійних колах активно обговорюється проблема оптимізації професійної діяльності психолога в школі в контексті раціонального розподілу затраченого, на кожний зазначений напрямок роботи, часу.

У низці наукових джерел акцентується увага на трудомісткості психодіагностики, яка забирає чимало часу та відволікає психолога від консультативної, психопрофілактичної та психокорекційної роботи $[1,6,7,10]$.

Надлишково занурюючись у психодіагностику, тестування, практичний психолог ризикує не помітити інші проблемні прикладні питання шкільного середовища, наприклад, пов'язані з ситуативними конфліктними взаємовідносинами між учасниками освітнього процесу, девіантною поведінкою учнів, булінг, тощо $[8,9,13]$.

Наголошуємо, що ефективність професійної діяльності психолога в освіті визначається результатами саме роботи з психокорекції емоційноособистісної сфери суб'єктів освітнього процесу, так як розвиток та психологічна корекція мотиваційних установок, життєвих цілей, ціннісних орієнтирів, інтересів (а не лише когнітивної сфери) учнів, учителів, батьків є найбільш пріоритетним завданням психологічної служби у системі освіти $[4,10,12]$. Тому, перед шкільним психологом постає актуальна професійна проблема: зуміти перерозподілити свій робочий час таким чином, щоб збільшити частку на психокорекційну діяльність, натомість розгорнутої психодіагностики особистості, при цьому, не втрачаючи якість останньої. Рішення поставленої проблеми знаходимо в наступному. Виходячи 3 того, що до об'єктивних умов оптимізації ефективності праці відноситься змістовне та науковометодичне забезпечення професійної діяльності психолога, з нашої точки зору, важливо доповнити наявний банк рекомендованого Міністерством освіти i науки України тестового матеріалу експрес-методиками варіативного характеру.

Безумовно, ефективність професійної діяльності шкільного психолога, переважно, визначається діагностичними можливостями тих опитувальників та методик, як розроблені у нинішньому соціокультурному просторі та пропонуються сучасною психологічною наукою $[3,5,11,14]$. Однак, більшість опитувальників містять значну кількість тверджень, що передбачає немалі зусилля та час для проведення психодіагностичного дослідження.

Слід відмітити, що з теоретико-методологічних позицій тестовий матеріал (більшість опитувальників), який використовують практичні психологи, опирається на позитивістські традиції, тобто дозволяє діагностувати окремі якості особистості, і тому досить обмежені у інформативному плані, що не відповідає вимогам практики сьогодення. 
Виходячи із вищесказаного, існує нагальна необхідність створення (розроблення) комплексу методичного інструментарію для психологів системи освіти, який би містив експрес-методики. Пропоновані експрес-методики, безумовно, мають мати відповідну валідність та надійність. У науковій психологічній літературі з психодіагностики ми не зустріли збірників, які б містили банк таких методик, за виключенням А.М. Бистрова [2].

Таким чином, використання експрес-методик психологічною службою школи дозволило б, на наш погляд, значно оптимізувати професійну діяльність психолога освіти.

В контексті обговорюваної проблематики слід відмітити такий тип методів, як візуальна психодіагностика, що здійснюється шляхом стороннього та включеного спостереження, а також вербальнокомунікативні методи (різні способи ведення психодіагностичної бесіди, інтерв'ю). За умови відповідного конструктивного підходу та широкої варіативності, ці групи інструментів досліджень можуть представляти собою експрес-психодіагностичні методи. При цьому, такі групи експрес-методів у своїй методологічній основі базуються на некласичній парадигмі, на якій зосереджується дедалі більший інтерес у сучасній психологічній науці.

Перевагою застосування експрес-методів, розроблених у некласичній парадигмі, є можливість за короткий час визначити психологічний портрет учня, вчителя чи батьків на основі їх поведінкової активності у реальних життєвих умовах. Серед небагатьох інших, освітнє середовище глибоко розкриває міжособистісні взаємовідношення між учасниками освітнього процесу. Відмітимо, що робота 3 комунікативно-візуальними методами передбачає високий рівень професійної компетентності та вимоги до особистості самого психолога, однак, обговорення цієї проблематики, виходить за рамки даної статті.

Доцільно окремо виділити групу проективних методів («Намалюй свою сім'ю», «Ставлення в сім’ї Жиля», «Намалюй людину», «Неіснуюча тварина», психогеометричний тест Деллінгера та інші), що також опираються на методологію некласичної психології.

Ми припускаємо, що частину проективних методів дослідження особистості у повній мірі можна віднести до групи експрес-методів, так як вони дозволяють зібрати за короткий час значний об'єм інформації про особистість. Акцент тут робиться на виявленні латентних, неявних, глибинних та важко усвідомлюваних якостях особистості, шляхом психодіагностичної оцінки емоційних реакцій респондента на невизначеність стимулів тестового матеріалу.

Висновки. Виявлена актуальна професійна необхідність розробити та використовувати у діяльності практичних психологів психодіаг100 
ностичний інструментарій - експрес-методики, які дозволять оптимізувати і підвищити ефективність роботи психологічної служби системи освіти.

Застосування експрес-методик надає можливість суттєво скоротити час на психодіагностику, не втрачаючи ії якість, тим самим збільшивши можливості для психокорекції (психологічне консультування, тренінги, індивідуальні та групові психолого-профілактичні бесіди тощо).

\section{Література:}

1. Бурлачук Л.Ф. Психодиагностика. СПб. : Питер, 2012. 384 с.

2. Быстров А.Н. Экспресс-диагностические методики в психологии. Учебное пособие. М. : ФЛИНТА, 2019. 360 с.

3. Горленко В.М., Острова В.Д., Сосновенко Н.В., Ткачук I.I. Методичні рекомендації. Київ: УНМЦ практичної психології і соціальної роботи, 2018. $106 \mathrm{c.}$

4. Демидова И.Ф. Рабочая книга психолога в старших классах. Ростов н/Д: Феникс, 2009. 249 с.

5. Лемак М.В., Петрище В.Ю. Психологу для роботи. Діагностичні методики: збірник. Ужгород: Видавництво Олександри Гаркуші, 2012. $616 \mathrm{c}$.

6. Максименко С.Д., Носенко Е.Л. Експериментальна психологія. Підручник. Київ. : Центр учбової літератури, 2008. 360 с.

7. Моргун В.Ф., Тітов І.Г. Основи психологічної діагностики: навч. посіб. Київ : Видавничий дім «Слово», 2013. 464 с.

8. Никандров В.В. Экспериментальная психология. СПб. : Речь, 2007. $512 \mathrm{c}$.

9. Носс И.Н. Руководство по психодиагностике. М.: Институт Психотерапии, 2005. 688 с.

10. Практикум по общей и экспериментальной и прикладной психологии / Под общей ред. А.А. Крылова, С.А. Маничева. СПб. : Питер, 2007. 560 с.

11. Рабочая книга практического психолога: Пособие для специалистов, работающих с персоналом / Под ред. А.А. Бодалева, А.А. Деркача, Л.Г. Лаптева. М.: Институт Психотерапии, 2001. 640 с.

12. Райгородский Д.Я. Практическая психодиагностика. Методики и тесты. Учебное пособие. Самара. Издательский Дом «Бахрах-М», $2001.672 \mathrm{c}$.

13. Рогов Е.И. Настольная книга практического психолога в образовании. Учебное пособие. М.: ВЛАДОС, 1995. 529 с.

14. Справочник практического психолога. Психодиагностика / Под общей ред. С.Т. Посоховой. М. : СПб. : Сова, 2005. 671 с. 